\title{
Organic and Inorganic Fertilizers Application on NPK Uptake and Production of Sweet Corn in Inceptisol Soil of Lowland Swamp Area
}

\author{
Neni Marlina ${ }^{1, *}$, Nurbaiti $\mathrm{Amir}^{2}$, R. Iin Siti Aminah ${ }^{2}$, Gamal Abdul Nasser ${ }^{1}$, Yani \\ Purwanti $^{1}$, Laili Nisfuriah ${ }^{1}$, and Asmawati $^{1}$ \\ ${ }^{1}$ Faculty of Agriculture UNPAL Palembang, Jl. Darmapala No 1A Bukit Lama Palembang Indonesia \\ ${ }^{2}$ Faculty of Agricultre UM Palembang, Jl. A. Yani 13 Ulu Palembang Indonesia
}

\begin{abstract}
This study objective was to determine the dose of organic and inorganic fertilizers which can increase N, P and $\mathrm{K}$ nutrients uptake as well as the growth and yield of sweet corn on inceptisol soil of lowland swamp. Inceptisol soil has low soil fertility and relatively low to moderate levels of organic matter content. Application of organic fertilizer on inceptisol soil of lowland swampis expected capable to increase N, P and K nutrients as well as yield of sweet corn. This research was conducted from April to July 2014 at Experimental Farm Area of Pulau Semambu Village, Indralaya Utara Subdistrict, Ogan Ilir District, South Sumatra Province. The method used in this research was randomized block design consisting treatments as follows: $75 \%$ inorganic fertilizer +5 ton.ha ${ }^{-1}$ organic fertilizer, $50 \%$ inorganic fertilizer +5 ton.ha ${ }^{-1}$ organic fertilizer, $25 \%$ inorganic fertilizer +5 ton.ha ${ }^{-1}$ organic fertilizer, $0 \%$ inorganic fertilizer + 5 ton.ha ${ }^{-1}$ organic fertilizer with six replications. The recommended dose of inorganic fertilizerswas $200 \mathrm{~kg} \cdot \mathrm{ha}^{-1}$ urea, $100 \mathrm{~kg} \cdot \mathrm{ha}^{-1} \mathrm{SP}-36$ and $100 \mathrm{~kg}$. $\mathrm{ha}^{-1} \mathrm{KCl}$. The results showed that treatment of $75 \%$ of inorganic fertilizer +5 ton.ha ${ }^{-1}$ organic fertilizer had produced $\mathrm{N}, \mathrm{P}$ and $\mathrm{K}$ nutrients uptake with magnitude of $1.850,0.418$ and 2.374 g.plant $^{-1}$ respectively as well as good growth and yield of sweet corn with magnitude of $356.36 \mathrm{~g}$. plant ${ }^{-1}$ or 15.21 ton $\mathrm{ha}^{-1}$.
\end{abstract}

\section{Introduction}

Sweet corn(Zea mays saccharata) seasonal crop that has high economic value because its seed has higher sugar content than that of other corn varieties. Sugar content of sweet corn is 14 to $18 \%$ which is close to sugar content of sugarcane crop with magnitude of $19 \%$, whereas sugar content of local sweet corn is only 9 to $11 \%$. Sweet corn has energy of 96 cal, Protein of $3.5 \mathrm{~g}$, Lipid of $1.0 \mathrm{~g}$, Carbohydrate of $22.8 \mathrm{~g}$, Calcium of $3.0 \mathrm{mg}$, Phosphorusof $111 \mathrm{mg}$, Iron of $0.7 \mathrm{mg}$, Vitamin A of $400 \mathrm{SI}$, Vitamin B of $0.15 \mathrm{mg}$,

* Coresponding author: marlina002@yahoo.com 
Vitamin C of $12.0 \mathrm{mg}$ andwater of $72.7 \mathrm{~g}$ [12].Sweet corn crop can also cultivated on suboptimal land such as lowland swamp.

Lowland swamp has very high potential to be developed in order to increase crop production such as sweet corn crop. Lowland swamp area in South Sumatra is relatively extensivewith magnitude of 368,685 hectares and most area was cultivated for rice crop and small area was cultivated for other crops such assweet corn crop [23].

The main problem in lowland swamp area is its physical constraint in form of water logging and chemical constraint in form of high soil acidity, $\mathrm{Al}$ and $\mathrm{Fe}$ cations which bind phosphorus and nutrients defficiency [13]. In addition, according to [3], soil fertility level in lowland swamp area is very low to medium so that fertilization effort is important to increase the productivity of lowland swamp.

Fertilizer is agricultural input that must be used in order to achieve maximum yield of sweet corn cultivated on lowland swamp area. However, the real problem experienced by farmers to increase productivity of lowland swamp through fertilization was frequently impeded by high price of inorganic fertilizer and its unavailability in site or location. Therefore, an alternative technology should be developed in order to increase crops yield and to decrease the dependenceon inorganic fertilizer (chemical fertilizer) at suboptimal land. This alternative technology should be economically feasible and technologically easy to be used by farmers, for instance the use of organic fertilizer (manure of chicken dunk). Ogan Ilir District is one of organic fertilizer producer (manure of chicken dunk) which can be utilized for sweet corn cultivation and capable to decrease the transportation cost.

Several study results in term of organic fertilizer on dry land had been published. Application of organic fertilizer in form of chicken dunk manure always produce the best crop response in the first season. This is due to the fact that organic fertilizer is relatively faster to be decomposed and has sufficient level of nutrients compared to other manures at the same weight unit [22]. According to Balittanah [25], nutrients content of chicken dunk manure is as follows: $1.70 \% \mathrm{~N}, \mathrm{C} / \mathrm{N}$ ratio of $10.80, \mathrm{P}$ of $2.12 \%$ and $\mathrm{K}$ of $1.45 \%$. In addition, according to Adimihardja [2], application of chicken dunk manure with dose of 5 ton.ha ${ }^{-1}$ on dry land (Ultisol in Jambi) had significant effect on increasing C-organic content and yield of corn and soybean.

The use of chicken dunk manure on soil can decrease environmental pollution, decrease heavy metals content which are toxic to crops [27] and can increase stem of ear cornweight of sweet corn with magnitude of 247.10 g.plant $^{-1}\left(11.57\right.$ ton.ha $\left.^{-1}\right)$ [12].It is expected that organic fertilizer combined with inorganic fertilizer if applied to lowland swamp can increase $\mathrm{N}, \mathrm{P}$ and $\mathrm{K}$ nutrients uptake as well as the growth and yield of sweet corn crop. This is in accordance to Permentan No 40/2007 which recommend the development of organic matter or application of organic fertilizer combined with inorganic fertilizer in order to improve soil condition and fertility all at onceto improve the usage efficiency of inorganic fertilizer [26].

\section{Methodology}

This research was conducted from April to July 2014 at Experimental Farm Area of Pulau Semambu Village, Indralaya Utara Subdistrict, Ogan Ilir District, South Sumatra Province. The method used in this research was randomized block design consisting treatments as follows: $75 \%$ inorganic fertilizer +5 ton. ha $^{-1}$ organic fertilizer, $50 \%$ inorganic fertilizer +5 ton.ha ${ }^{-1}$ organic fertilizer, $25 \%$ inorganic fertilizer +5 ton.ha ${ }^{-1}$ organic fertilizer, $0 \%$ inorganic fertilizer +5 ton. ha $^{-1}$ organic fertilizer with six replications. The recommended dose of inorganic fertilizerswas $200 \mathrm{~kg} \cdot \mathrm{ha}^{-1}$ urea, $100 \mathrm{~kg} \cdot \mathrm{ha}^{-1} \mathrm{SP}-36$ and $100 \mathrm{~kg}$. ha ${ }^{-1} \mathrm{KCl}$. Organic fertilizer dose (chicken dunk manure) was 5 ton.ha ${ }^{-1}$.The further test was 
conducted by using Least Significant Different (LSD) at 5\% level, whereas regression and correlation analysis was used to determine the relationship between N, P and K nutrients uptake and stem of ear cornweight of sweet corn. Statistical analysis was done by using SAS 9.1.3 Portable program.

\subsection{Land preparation}

Land was cleared from the existing vegetation two weeks before planting and two tillages operation were conducted until soil become loosefollowed by development of 24 plots.

\subsection{Planting}

Planting was done by planting two seeds per planting hole with dibblemethod. The planting distance was $75 \mathrm{~cm} \times 25 \mathrm{~cm}$.

\subsection{Fertilizing}

Addition of manure was conducted at the same time with soil tillage period. Urea fertilizer was applied two times, i.e. 1/3 part during planting and 2/3 part at period of 4 weeks after planting, whereas SP-36 and $\mathrm{KCl}$ fertilizers were given during the planting period.

\subsection{Crop maintenance}

Crop maintenance was consisted of watering (irrigation), replacement, thinning out, heapingand weeds clearing. The watering operation was done every day in morning and afternoon period. Replacementwas done one week after planting. Thinning outwas done one week after planting. Heaping and weeds clearingwas done two weeks after planting.

\subsection{Harvest}

Harvest was done after crop was at period of about 60-70 days after planting which was indicated by come out ofcorn hairs having brown color and corn seeds were still soft and fully filled.

The observed parameters were soil analysis before planting, crop height $(\mathrm{cm})$, leave numbers (sheets), stem of ear corndiameter $(\mathrm{cm})$, stem of ear cornlength $(\mathrm{cm})$, uptake of $\mathrm{N}$, $\mathrm{P}$ and $\mathrm{K}$ nutrients, stem of ear cornweight per plant $(\mathrm{g})$ and stem of ear cornweight per hectare (tons).

\section{Results and discussion}

\subsection{Results}

\subsubsection{Soil characteristics before treatment}

The observed characteristics of soil chemical properties were consisted of soil $\mathrm{pH}, \mathrm{C}$ organic content, $\mathrm{N}$ total, P-available, K-dd, Na-dd, Ca-dd, Mg-dd, Cation Exchange 
Capacity, H-dd, Al-dd andC/N ratio.Results of soil chemical analysis can be seen in Table 1.

Based on research criteria according to [17] and [25], soil used in this research was classified as acid soil $\left(\mathrm{pH} \mathrm{H}_{2} \mathrm{O}=4.20\right)$ with high cation exchange capacity $\left(29.23 \mathrm{cmol}_{(+)} \mathrm{kg}^{-}\right.$ $\left.{ }^{1}\right)$, C-organic content classified as medium $(2.67 \%), \mathrm{C} / \mathrm{N}$ ratio classified as medium (8.34), $\mathrm{N}$-total content classified as low (0.32\%), P-available classified as high $\left(216.62 \mathrm{mg} \mathrm{kg}^{-1}\right)$, exchangable bases such as Ca-ddclassified as low $\left(4.03 \mathrm{cmol}_{(+)} \mathrm{kg}^{-1}\right), \mathrm{Mg}$-dd classified as high $\left(0.26 \mathrm{cmol}_{(+)} \mathrm{kg}^{-1}\right)$, K-dd classified as low $\left(0.27 \mathrm{cmol}_{(+)} \mathrm{kg}^{-1}\right)$, Na-ddclassified as low $\left(0.61 \mathrm{cmol}_{(+)} \mathrm{kg}^{-1}\right)$, base saturation classified as very low (17.63) and Al-dd of $1.27 \mathrm{cmol}_{(+)}$ $\mathrm{kg}^{-1}$.

Table 1. Soil chemical analysis resultsprior to planting.

\begin{tabular}{|c|c|c|c|}
\hline No. & Analysis type & Analysis results & Evaluation $^{*}$ \\
\hline 1. & $\mathrm{pH} \mathrm{H}_{2} \mathrm{O}(1: 1)$ & 4.20 & Very acid \\
\hline 2. & $\mathrm{C} / \mathrm{N}$ ratio & 8.34 & Low \\
\hline 3. & C-organic $(\%)$ & 2.67 & Medium \\
\hline 4. & N-total (\%) & 0.32 & Low \\
\hline 5. & P Bray I $\left(\mu \mathrm{g} \mathrm{g}^{-1}\right)$ & 216.62 & High \\
\hline 6. & Ca-dd $\left(\mathrm{cmol}_{(+)} \mathrm{kg}^{-1}\right)$ & 4.03 & Low \\
\hline 7. & $\operatorname{Mg}$-dd $\left(\mathrm{cmol}_{(+)} \mathrm{kg}^{-1}\right)$ & 0.26 & Very low \\
\hline 8. & $\mathrm{~K}-\mathrm{dd}\left(\mathrm{cmol}_{(+)} \mathrm{kg}^{-1}\right)$ & 0.27 & Low \\
\hline 9. & Na-dd $\left(\mathrm{cmol}_{(+)} \mathrm{kg}^{-1}\right)$ & 0.61 & Low \\
\hline 10. & Base saturation (\%) & 17.63 & Very low \\
\hline 11. & Al-dd $\left(\mathrm{cmol}_{(+)} \mathrm{kg}^{-1}\right)$ & 1.27 & \\
\hline 12. & Al saturation & 1.14 & Very low \\
\hline
\end{tabular}

Remarks: Analysis results from Nubika Laboratory, Bogor (2014)

*Soil Research Center (1983) and Soil Research Council (2005)

\subsubsection{Vegetative Growth of Sweet Corn Crop}

Results of variance analysis showed that organic fertilizer and inorganic fertilizer treatments had significant effect on leave numbers, stem of ear corn diameter, N, P and K nutrients uptake, but had no significant effect on other parameters. The summary of variance analysis results wer shown in Table2.

Table 3 showed that the highest value of average crop height and the highest leave numbers was found on treatment of $75 \%$ inorganic fertilizer +5 ton ha $^{-1}$ organic fertilizer with magnitude of $217.60 \mathrm{~cm}$ and 17.24 sheets, respectively; whereas the lowest value of average crop height and the lowest leave numbers was found on treatment of $0 \%$ inorganic fertilizer +5 ton ha $^{-1}$ organic fertilizer with magnitude of $209.08 \mathrm{~cm}$ and 17.08 sheets, respectively. Treatment of $75 \%$ inorganic fertilizer +5 ton ha $^{-1}$ organic fertilizer was significantly different than treatments of $50 \%, 25 \%$ and $0 \%$ inorganic fertilizer +5 ton.ha ${ }^{-1}$ organic fertilizer in term of $\mathrm{N}, \mathrm{P}$ and $\mathrm{K}$ nutrients uptake. There was very close relationship between doses of organic ferilizer + inorganic fertilizer and $\mathrm{N}, \mathrm{P}$ and $\mathrm{K}$ nutrients uptake (see Figure 1, 2 and 3). 
Table 2. Calculated value of $\mathrm{F}$ for the observed parameters.

\begin{tabular}{|c|c|c|c|c|c|}
\hline $\begin{array}{l}\text { Source of } \\
\text { Variation }\end{array}$ & $\begin{array}{l}\text { Crop height } \\
(\mathrm{cm})\end{array}$ & $\begin{array}{c}\text { Leave numbers } \\
\text { (sheets) }\end{array}$ & $\begin{array}{l}\mathrm{N} \text { uptake } \\
\left(\text { g.plant }{ }^{-1}\right)\end{array}$ & P uptake(g.plant $\left.{ }^{-1}\right)$ & $\begin{array}{l}\text { K uptake } \\
\left(\text { g.plant }{ }^{-1}\right)\end{array}$ \\
\hline $\begin{array}{c}\text { Inorganic } \\
\text { fertilzer }+ \\
\text { organic } \\
\text { fertilizer }\end{array}$ & $\begin{array}{c}\text { Not } \\
\text { significant }\end{array}$ & Not significant & Significant & Significant & Significant \\
\hline
\end{tabular}

Table 3. The effect of inorganic and organic fertilizers on crop height, leave numbers and N, P and K nutrients uptake.

\begin{tabular}{|c|c|c|c|c|c|}
\hline $\begin{array}{l}\text { Inorganic fertilzer }+ \\
\text { organic fertilizer(\%) }\end{array}$ & $\begin{array}{l}\text { Crop height } \\
\text { (cm) }\end{array}$ & $\begin{array}{c}\text { Leave } \\
\text { numbers } \\
\text { (sheets) }\end{array}$ & $\begin{array}{l}\text { N uptake } \\
(\text { g.plant }\end{array}$ & $\begin{array}{l}\text { P uptake } \\
\left(\text { g.plant }{ }^{-1}\right)\end{array}$ & $\begin{array}{l}\text { K uptake } \\
(\text { g.plant } \\
\text { (-) }\end{array}$ \\
\hline $75+$ po 5 ton.ha ${ }^{-1}$ & 217.60 & 17.24 & $1.850 \mathrm{c}$ & $0.418 \mathrm{~d}$ & $2.374 \mathrm{~d}$ \\
\hline $50+$ po5 ton.ha ${ }^{-1}$ & 216.36 & 17.08 & $1.790 \mathrm{~b}$ & $0.368 \mathrm{c}$ & $1.922 \mathrm{c}$ \\
\hline $25+$ po5 ton.ha ${ }^{-1}$ & 214.88 & 17.08 & $1.638 \mathrm{a}$ & $0.348 \mathrm{~b}$ & $1.594 \mathrm{~b}$ \\
\hline $0+$ po 5 ton.ha ${ }^{-1}$ & 209.08 & 17.08 & $1.628 \mathrm{a}$ & $0.338 \mathrm{a}$ & $1.208 \mathrm{a}$ \\
\hline HSD $0.05=$ & Ns & ns & 0.030 & 0.006 & 0.001 \\
\hline
\end{tabular}

Remarks: Numbers followed by the same letters in the same column are represent not significantly different.

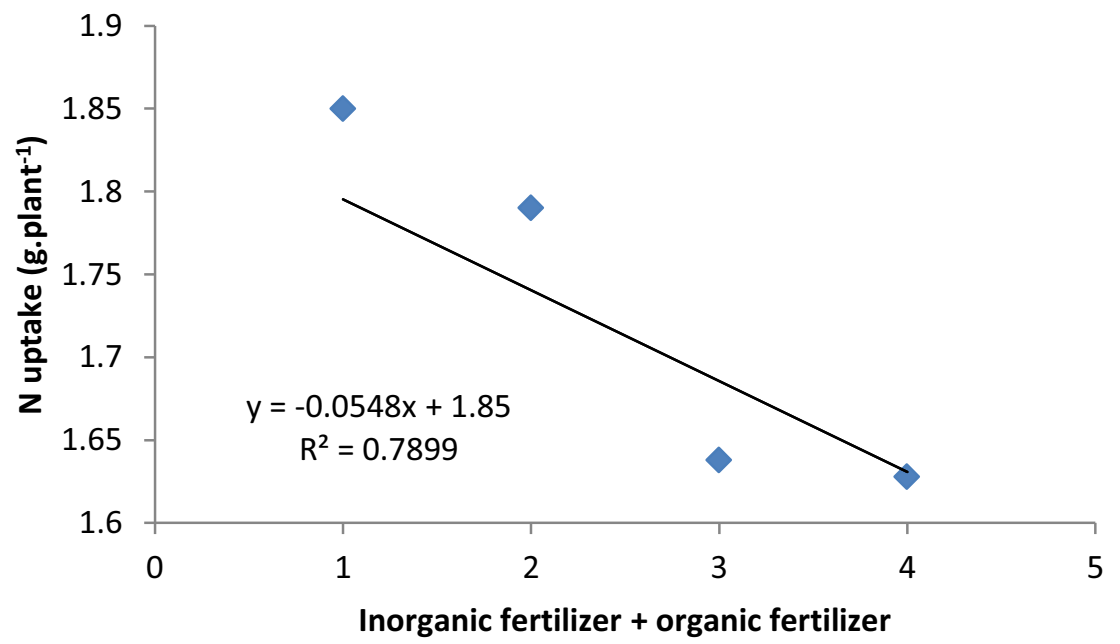

Fig. 1. Relationship between inorganic and organic fertilizers and N nutrient uptake 


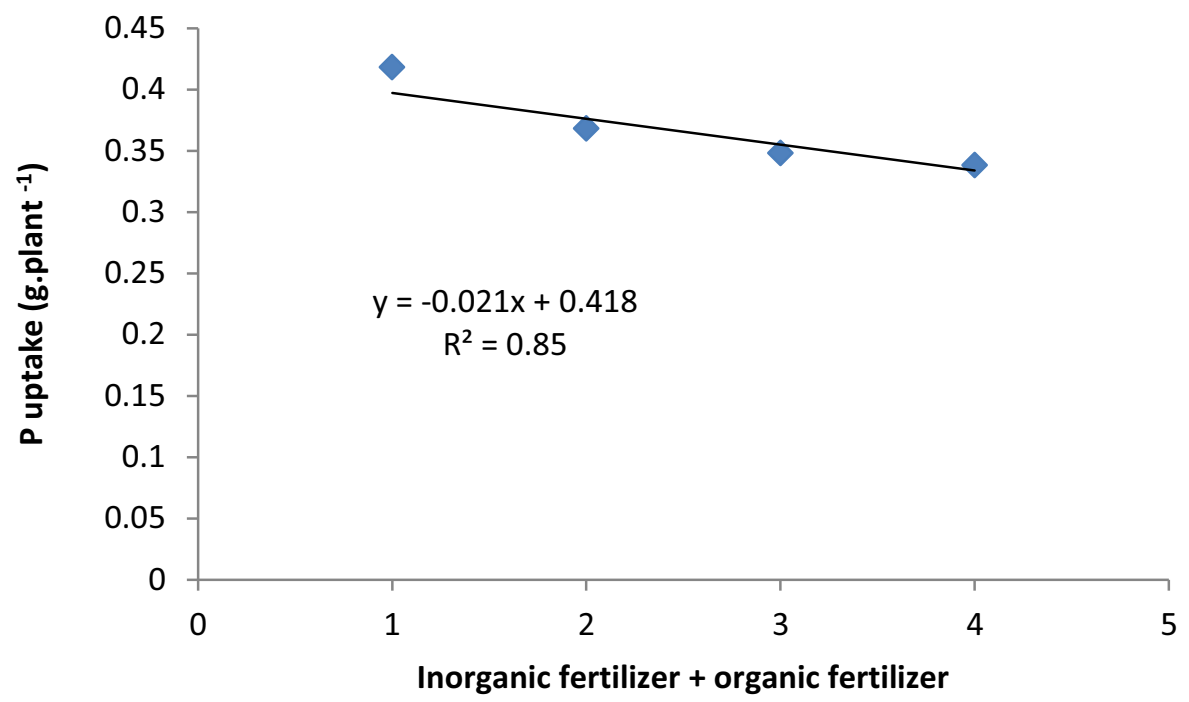

Fig. 2. Relationship between inorganic and organic fertilizers and P nutrient uptake

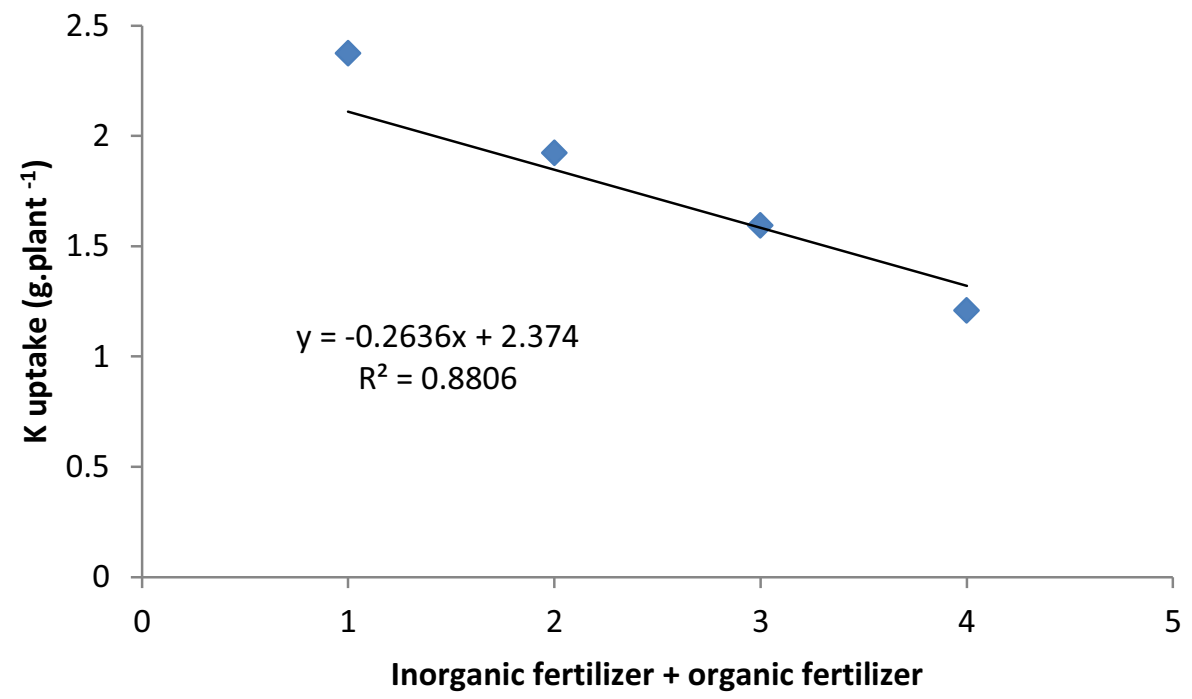

Fig. 3. Relationship between inorganic and organic fertilizers and $\mathrm{K}$ nutrient uptake

Figure 1, 2 and 3 showed that there was very close relationship amongst inorganic fertilizer + organic fertilizer and N, P and K nutrients uptake which was shown by $\mathrm{R}^{2}$ values of $0.789,0.850$ and 0.880 as well as $r$ values of $0.890,0.920$ and 0.940 . It means that every addition of organic fertilizer to lower dose of inorganic fertilizer would results in decrease of $\mathrm{N}, \mathrm{P}$ and $\mathrm{K}$ nutrients uptake with magnitude of $0.054 \mathrm{x}, 0.021 \mathrm{x}$ and $0.263 \mathrm{x}$, respectively. 


\subsubsection{Production of sweet corn crop}

Results of variance analysis showed that application of organic and inorganic fertilizers had no significant effect on stem of ear corn length, stem of ear corn weight per plant and stem of ear corn weight per hectare. The summary of variance analysis results for the observed parameters can be seen in Table 4 .

Table 5 showed that the highest average values of stem of ear corn length, stem of ear corn weight per plant and stem of ear corn weight per hectare was found on treatment of 75 $\%$ inorganic fertilizer +5 ton.ha $^{-1}$ organic fertilizer with magnitude of $20.76 \mathrm{~cm}, 356.36$ g.plant ${ }^{-1}$ and 15.21 ton.ha $^{-1}$, whereas the lowest average values of stem of ear corn length, stem of ear corn weight per plant and stem of ear corn weight per hectare was found on treatment of $0 \%$ inorganic fertilizer +5 ton.ha ${ }^{-1}$ organic fertilizer with magnitude of 17.08 $\mathrm{cm}, 333.68$ g.plant ${ }^{-1}$ and 14,24 ton.ha ${ }^{-1}$, respectively.

Table 4. Values of calculated F for the observed parameters.

\begin{tabular}{|c|c|c|c|}
\hline Source of Variation & $\begin{array}{c}\text { Stem of ear corn } \\
\text { length }(\mathrm{cm})\end{array}$ & $\begin{array}{c}\text { Stem of ear corn weight } \\
\text { per plant }(\mathrm{g})\end{array}$ & $\begin{array}{c}\text { Stem of ear corn } \\
\text { weight per hectare } \\
\text { (ton) }\end{array}$ \\
\hline $\begin{array}{c}\text { Inorganic fertilizer }+ \\
\text { organic fertilizer }\end{array}$ & Not significant & Not significant & Significant \\
\hline
\end{tabular}

Table 5. The effect of inorganic fertilizer and organic fertilizer on stem of ear corn length, stem of ear corn weight per plant and stem of ear corn weight per hectare

\begin{tabular}{|c|c|c|c|}
\hline $\begin{array}{c}\text { Inorganic fertilizer }+ \\
\text { organic fertilizer }(\%)\end{array}$ & $\begin{array}{c}\text { Stem of ear } \\
\text { corn length } \\
(\mathrm{cm})\end{array}$ & $\begin{array}{c}\text { Stem of ear corn } \\
\text { weight per plant }(\mathrm{g})\end{array}$ & $\begin{array}{c}\text { Stem of ear corn } \\
\text { weight per } \\
\text { hectare (ton) }\end{array}$ \\
\hline $75+$ po & 20.76 & 356.36 & 15.21 \\
\hline $50+$ po & 20.58 & 354.96 & 15.14 \\
\hline $25+$ po & 20.56 & 348.52 & 14.78 \\
\hline $0+$ po & 17.08 & 333.68 & 14.24 \\
\hline BNJ 0,05= & $\mathrm{ns}$ & $\mathrm{ns}$ & $\mathrm{ns}$ \\
\hline
\end{tabular}

Remarks: Numbers followed by the same letters in the same column are represent not significantly different.

\subsection{Discussion}

\subsubsection{Soil characteristics before treatment}

Soil used in this study had low $\mathrm{pH}$ and very acid as well as low N-total content. Although availability of $\mathrm{P}$ is high, but available $\mathrm{P}$ was also low because most of it was bindedby $\mathrm{Al}$ which produce Al-P so that $\mathrm{P}$ nutrient can not be absorbed by sweet corn crop.

Low value of $\mathrm{pH} \mathrm{H}_{2} \mathrm{O}$ in this soil was due to the fact that this soil had been used for years for agricultural enterprise and used chemical fertilizer, especilly urea. One molecule of urea can contribute $4 \mathrm{~mol}$ ions of $\mathrm{H}^{+}$into soil which subsequently produce soil acidity. Soil in this research location also had higher quantity of metal ions such as $\mathrm{Fe}, \mathrm{Cu}, \mathrm{Mn}$ and $\mathrm{Zn}$ when hydrolized would contribute $\mathrm{H}^{+}$ions into soil.

Soil in this lowland swamp has low fertility level which is showed by very acid soil $\mathrm{pH}$ and this is oen ciri of inceptiol soil. According to [1], inceptiol soilhas low fertility level and acid soil $\mathrm{pH}$. This condition is exageratedby limited use of organic fertilizer, especially on seasonalfood crops. Inceptisol soil is characterized by loamy textural class, soil reaction 
in the range of relative acid to relative alkaline, nutrient content and nutrient supply were relatively medium and cation exchange capacity in the range of medium to high.

Soil condition used in this research was not provide good support for the growth of sweet corn crop so that this soil should be added with inorganic fertilizer and organic fertilizer (chicken dunk manure). This organic fertilizer has function as source of organic acids which capable to control metals precipitation in soil or as nutrients source for crops. Decomposition result might be in form of organic acids which can chelate metal ions so that $\mathrm{P}$ which bounded by metal ions (Al-P and Fe-P) can be released and become available again. This available $\mathrm{P}$ can be utilized by sweet corn crop for good growth and production.

Organic acids available in organic fertilizer can chelate toxic elements (metals) in soil so that soil condition is not harmful for crop growth [22] and [7]. Organic acids are capable to decrease phosphate quantity which fixedby $\mathrm{Fe}$ and $\mathrm{Al}$ through chelating mechanisms so that $\mathrm{P}$ is become available for crops (Barker dan Pilbeam, 2007). Pengikatan mechanisms of $\mathrm{Fe}$ and $\mathrm{Al}$ was done by functional groupof organic component due to availability of carboxyl groupwhich close to and react with metal ions.

\subsubsection{Vegetative growth of sweet corn crop}

Results of the study showed that organic fertilizer application was very helpful in providing nutrients which is highly required by sweet corn crop either in addition with inorganic fertilizer or without addition of inorganic fertilizer.

There was an interesting phenomenon in which application of 5 ton.ha ${ }^{-1}$ organic fertilizer followed by application of $0 \%$ to $75 \%$ recommended dose of inorganic fertilizers had produced good growth of crop height, leave numbers and good nutrients uptake of N, P and $\mathrm{K}$ for sweet corn crop. This was due to the fact that soil analysis results before planting showed low availability of N, P and K nutrients as well as low base saturation. Therefore, sweet corn crop had good positive response to the addition of organic and inorganic fertilizers. This positive response was estimated due to excessive organic fertilizer that capable to increase soil absorption to water and to help nutrients absorbption from inorganic fertilizer. This organic fertilizer was quickly decomposed so that nitrate production rate was readily available for crops. Nitrate absorbed by sweet corn crop has a role in increasing the crop growth and formation of leave numbers.

Organic fertilizer has a role in improving soil fertility. Nutrients content in organic fertilizer is not high, but it has specific characteristics, i.e. improving soil physical properties such as soil permeability, soil porosity, soil structure, water holding capacity and soil cations [9], [6]. N nutrient from urea has a role for leave development, but this nutrient is easily leached so that organic matter is required to increase water holding capacity and soil cations.

Nutrients content within organic fertilizer, soil and nutrients addition from chemical fertilizer which are absorbed by crops will be translocated on vegetative parts of crop. These nutrients are highly required especially during meddle ingenerative growth of crop for flowering and seed development processes. According to [21], organic fertilizer (manure) is nitrogen source that will give the fastest and significant effects on crop growth compared to other elements.

Crop height affects leave numbers. The higher the crop height, the more was the leave numbers. Increase of leave numbers results in increase of photosynthesis process which is indicated by the increase of N, P and K nutrients uptake (Figure 1, 2 and 3). The increase of $\mathrm{N}, \mathrm{P}$ and $\mathrm{K}$ nutrients uptake can be used by crop to increase its vegetative parts such as crop height and development of leave numbers. 


\subsubsection{Production of Sweet Corn Crop}

Application of 5 ton.ha ${ }^{-1}$ organic fertilizer $+75 \%$ inorganic fertilizer had produced higher magnitude of stem of ear corn length, stem of ear corn weight per plant and stem of ear corn weight per hectare than that of application of 5 ton.ha ${ }^{-1}$ organic fertilizer $+50 \%, 25 \%$ and $0 \%$ inorganic fertilizers. This results were estimated due to the fact that organic fertilizer application has highly significant role in improving environmental condition of roots zone for sweet corn and in helping nutrients availability from unavailable to available condition for crop. If the growth environment of roots is better, then nutrients will be absorbed by crops either from organic fertilizer or from inorganic fertilizer to support photosynthesis process and cell formation or cell enlargement which has direct effect in increasing nutrients uptake of $\mathrm{N}, \mathrm{P}$ and $\mathrm{K}$, crop growth and yield of sweet corn crop. According toAgromedia (2007), crops require the proper nutrients in term of type and quantity for their growth and production processes.

In addition, production of sweet corn crop (tongkol weight per plant and tongkol weight per hectare) is highly affected by the growth of crop height, leave numbers and nutrients uptake of N, P and $\mathrm{K}$ by crop itself. Transportation of nitrogen, phosphorusand potassiumas well as photosyntate from leaves was very greatduring seed filling process. Nitrogen controls the use of phosphoruswhich stimulate flowering and fruit formation processes. It is estimatedthat organic fertilizer during this period had been continously decomposed and nitrogen as well as other nutrients became more available when crops meddle inflowering and seed filling processes. According to Soepardi (1983) and Hanafiah (2005), nitrogen has function to stimulate the growth and to increase protein content of cereal crops as well as to regulate the use of phosphorus, potassiumand other nutrients. According to Lingga and Marsono (2008), nitrogen has a role in stimulating the overall growth and leave chlorophyleformation which is very important in photosynthesis process.In addition, nitrogen has a role in formation of protein, lipid and other organic cmpounds. This is supported by study results of Nurdin et al. (2009) which showed that appication of NPK fertilizer could produced corn crop height of $175.25 \mathrm{~cm}$.

$\mathrm{P}$ elementhas a role in flower, fruit and seed formations. Availability of $\mathrm{P}$ elementwithin soil is very low. Most of $\mathrm{P}$ elementis in unavailable formthat can not be absorbed by crop and fixation of $\mathrm{P}$ by $\mathrm{Al}$ is occurred within acid soil or fixation of $\mathrm{P}$ by $\mathrm{Ca}$ is occurred within alkaline soil (Hardjowigeno, 2003). Application of manure can neutralize acid soil and application of NPK fertilizer can provide $\mathrm{P}$ unsur requirement for crops.

The sweet taste on sweet corn is estimateddue to availability of potassiumnutrients. Potassiumis absorbed in form of $\mathrm{K}^{+}$ion. Salisbury and Ross (1992) had stated that K+ has a role in starch formation as sintetase starch enzyme activator. This is one of reason why $\mathrm{K}+$ is important for crop and why sugar instead of starch which is heapedwithin crop that experience potassiumdefficiency. The study results from Maruapey and Faesal (2010) showed that application KCL fertilizer dose of $100 \mathrm{~kg} \cdot \mathrm{ha}^{-1}$ had produced the highest value of biomass weight with average value of $11.083 \mathrm{~kg} \cdot \mathrm{ha}^{-1}$ and high amylopectine content.

Tongkol length and diameter showed the form of tongkol itself which can affect tongkol weight. Higher values of tongkol length and tongkol diameter will produce higher magnitude of seed numbers in tongkol which in turn produce higher magnitude of tongkol weight (Table 5).

Results of this study in overall showed that sweet corn crop require good environment for roots growth ad balance nutrients if we want to apply balance fertilizing either by using organic fertilizer or inorganic fertilzer. Balance fertilizing is location specific nutrients management which depend on local environment, especially soil. According to 
Dobermann et al. (2003) in [20], concept of location specific nutrients management should take into account soil capability to provide nutrients naturally and nutrients recovery that had been previously used by crops. The similar concept is also used for new fertilizing recommendation for corn crop with specific emphasize on understanding of potential yield and gapyield as a base for recommendation improvement of location specific nutrient management.Nutrients management of location specific is an effort to provide nutrients for crops properly in term of quantity, types and application time by considering crop requirement and land capacity in providing nutrients for crops.

\section{Conclusion}

It can be concluded that application of 5 ton.ha ${ }^{-1}$ organic fertilizer $+75 \%$ inorganic fertilizer could increase N, P and K nutrients uptake (1.850, 0.418 and 2.374 g.plant $^{-1}$ ) as well as good growth and yield of sweet corn crop with magnitude of 356.36 g.plant $^{-1}$ or 15.21 ton.ha ${ }^{-1}$.

The writers want to deliver acknowledgement to Bambang Tulistiono which had provided signficant help in the field work.

\section{References}

1. A. Abdurachman, A. Dariah, A. Mulyani, J. Agrie. Res., 27(2), 43 (2008)

2. A. Adimihardja, I. Juarsah, U. Kurnia, Proceeding of National Seminar of Soil Resources, Climate and Fertilizer, (Book II. Lido Bogor, 1999)

3. T. Alihamsyah, Ar Riza, Potential and Technology of Lowland Swamp Utilization for Agriculture. Main Paper of National Workshop for Lowland Swamp Development, (Regional Government of Hulu Sungai District and Agricultural Council of South Kalimantan Province, Kandangan, 2004)

4. Agricultural Research and Development, The Map of Inorganic Fertilizer Saving Potential and Organic Fertilizer Development on Paddy Field in Indonesia, (Agriculture Ministry, Indonesia 2010)

5. A.V Barker, D.I. Pilbeam, Handbook of Plant Nutririon, (CRC Press, New York, 2007)

6. D. Budianta, D. Ristiani, Soil Fertility Management to Support Conservation of Land Resource and Environment, (UNSRI Press, Palembang 2013)

7. Dubey, India Soil Sci., 45, 506 (1997)

8. K.A. Hanafiah, Principles of Soil Science, (RajaGrafindo, Jakarta 2005)

9. S. Hardjowigeno, Soil Science, (Akademika Pressindo, Jakarta 2003)

10. W. Hartatik, L.R. Widowati, Manure, Organic Fertilizer and Biofertilizer. Research and Development Council of Agriculural Land Resource, (Agricultural Research and Development Council, Bogor 2005)

11. D. Iskandar, National Seminar of Teknologi Negeri, Pusat Teknologi Negeri, Vol. II, (Jakarta, 2003)

12. P. Lingga, Marsono, Fertilizer Use Guidance, (Penebar Swadaya, Jakarta 2008)

13. A. Maruapey, Faesal, Proceeding of National Cereal Day, (2010)

14. A. Maruapey, Cereal National Seminar, 23 (2011)

15. M. Noor, Lowland Swamp: Technology, Utilization and Its Development, (Rajawali Pers., Jakarta, 2007)

16. P. Nurdin, Z. Maspeke, Ilahude, F. Zakaria, Journal of Tropical Soil., 14(1), 49 (2009) 
17. Soil Research Center, Terms of Reference Type, (P3TT, Bogor, 1983)

18. Redaksi Agromedia, Fertilizing Guidance, (Agromedia Pustaka, Jakarta, 2007)

19. F.B. Salisbury, W.C. Ross, Crop Physiology: Part 2, (ITB Press, Bandung, 1992)

20. M.P. Sirappa, Increasing of Corn Productivity Through Application of N, $P$ and $K$ Fertilizers as well as Manure in Dry Land, (Agricultural Technology Research Council, Maluku, Ambon, 2010)

21. G. Soepardi, Properties and Characteristics of Soil, (IPB, Bogor, 1983)

22. F.J. Stevenson, Humus Chemistry, Genesis, Composition, Reaction, (John Wiley and Son Inc., New York, USA, 1984)

23. H. Subagyo, Lowland Swamp, (Research and Development Council of Agricultural Land Resource Development, Bogor, 2006)

24. L.R. Widowati, U. Sri Widati, Jaenudin, W. Hartatik, The Effect of Compost Enriched with Minerals and Biofertilizer on Soil Properties, Nutrients Uptake and Organic Vegetable Production, (Soil Research Council, 2005) 